\title{
Article \\ Influence of Nutrient-Stress Conditions on Chlorella vulgaris Biomass Production and Lipid Content
}

\author{
Patryk Ratomski (D) and Małgorzata Hawrot-Paw * (D) \\ Department of Renewable Energy Engineering, West Pomeranian University of Technology in Szczecin, \\ Pawla VI 1, 71-459 Szczecin, Poland; patryk.ratomski@zut.edu.pl \\ * Correspondence: malgorzata.hawrot-paw@zut.edu.pl
}

Citation: Ratomski, P.; Hawrot-Paw, M. Influence of Nutrient-Stress Conditions on Chlorella vulgaris Biomass Production and Lipid Content. Catalysts 2021, 11, 573. https:// doi.org/10.3390/catal11050573

Academic Editors:

Consuelo Alvarez-Galvan and Jose M. Campos-Martin

Received: 30 March 2021

Accepted: 28 April 2021

Published: 29 April 2021

Publisher's Note: MDPI stays neutral with regard to jurisdictional claims in published maps and institutional affiliations.

\begin{abstract}
Microalgal biomass and its cellular components are used as substrates for the production of fuels. A valuable group among the components of microalgal biomass is lipids, which act as a precursor for the production of biodiesel in the transesterification process. Some methods, including the creation of stressful conditions, are applied to increase the accumulation of lipids. This study aimed to determine the effect of limited nutrient access on the growth and development of the microalga Chlorella vulgaris and the amount of lipids stored in its cells. Aquaculture wastewater (AWW) was used in the study as a source of nutrients at doses of $20 \%, 40 \%, 60 \%, 80 \%$ and $100 \%$. The amount of microalgal biomass, optical density, lipid content after extraction of the biomass in Soxhlet apparatus and chlorophyll a content were determined. It was observed that the microalgae efficiently used the nutrients contained in the AWW. The largest amount of biomass was obtained in $\mathrm{AWW}_{80}\left(727 \pm 19.64 \mathrm{mg} \cdot \mathrm{L}^{-1}\right)$. The $\mathrm{OD}_{680}(0.492 \pm 0.00)$ determined under the same conditions was almost five times higher in AWW than in the synthetic medium. Under nutrient-stress conditions, the content of lipids in biomass ranged from $5.75 \%\left(\mathrm{AWW}_{80}\right)$ to $11.81 \%\left(\mathrm{AWW}_{20}\right)$. The highest content of chlorophyll a in microalgal cells was obtained in $\mathrm{AWW}_{20}\left(206 \pm 11.33 \mathrm{mg} \cdot \mathrm{m}^{-3}\right)$.
\end{abstract}

Keywords: nutrient limitation; stress conditions; microalgal biomass; lipid content; aquaculture wastewater

\section{Introduction}

The use of conventional energy sources leads to a number of problems including global warming, environmental degradation and energy crises [1]. Due to these threats, there is an urgent need to develop sustainable and novel environmentally friendly energy sources. Microalgae seem to be an ideal raw material for the production of biofuels. Compared to the biomass of terrestrial plants used for energy purposes, microalgal biomass is characterized by a lower water footprint, higher photosynthetic efficiency, the ability to grow on marginal soils and the possibility of using waste streams, including carbon dioxide, as a source of nutrients for cell growth and development [2]. Moreover, a lack of competition with edible plants for the cultivation area means improved food safety [3].

Despite many advantages, the use of microalgae for energy purposes is associated with several limitations, including economic competitiveness and the feasibility of largescale biofuel production, as well as high investment costs which constitute a significant barrier to potential investment $[4,5]$. Therefore, it is necessary to improve the production of biofuels from algae and increase economic profitability. This can be achieved by developing an appropriate technology through the optimization of growing conditions [6], taking into account the nutrient availability, temperature changes, salinity, supplementation with plant hormones and differentiation of light intensity [7-9].

Under optimal conditions of cultivation, microalgae show high biomass growth but do not accumulate a large amount of reserve materials $[10,11]$ such as carbohydrates or lipids which are useful for biofuel production [12]. The typical abiotic stress factors that significantly affect the biochemical composition of algal cells include lipid production, extreme temperatures, lighting, the amount of carbon dioxide, UV exposure, salt content and 
nutrient starvation [13-18]. An unfavorable culture condition may change the metabolism of fatty acids toward the biosynthesis and accumulation of triacylglycerols, which may constitute up to $80 \%$ of the total lipid content in the cell. The main factor that influences fatty acid metabolism is the limitation of nitrogen availability [19]. Under limited nitrogen access, many microalgal species produce and accumulate a large amounts of lipids [20-22]. However, the lack of nitrogen, which is responsible for increasing the content of proteins and assimilation pigments in cells, causes a reduction in the productivity of biomass. The chlorophyll content in microalgal cells is an indicator of the intensity of photosynthesis and photochemical processes during which the energy accumulated in ATP is generated [23]. Thus, an important element in the development of a technology for biofuel production using microalgae is determining the appropriate doses of nutrients, which would enable achieving a high production of lipids as well as a high efficiency of biomass growth [24]. Additionally, it is necessary to ensure optimal culture conditions, including temperature, $\mathrm{pH}$, mixing $[25,26]$ and lighting, which should be evenly distributed to allow the photons to reach the entire volume of the photobioreactor [27].

The supply of nutrients for the production of microalgae biomass [28] can be associated with the purification of the aquatic environment [29] and the removal of nutrients, including nitrogen and phosphorus, which cause water eutrophication [30]. Microalgae can be potentially used in the treatment of municipal industrial wastewaters, agricultural wastewaters and post-cultivation waters. Moreover, the use of microalgae in disposal processes has been economically justified [31].

This study assessed the growth and development of the microalga Chlorella vulgaris in saline aquaculture wastewater (AWW) used in different doses. It was hypothesized that diluting the wastewater and thus limiting the nitrogen content in the culture medium would have a positive effect on increasing the content of lipids in microalgal cells. Additionally, the content of chlorophyll a was determined in the microalgal biomass.

\section{Results and Discussion}

\subsection{Production of Chlorella vulgaris Biomass in Aquaculture Wastewater}

The biomass of $C$. vulgaris can serve as a source of valuable chemical components, and as an additive to animal feed and human food. Its production can also be utilized for the treatment of wastewaters [32]. Statistical analysis of the results obtained in this study showed that the AWW doses had a significant effect on biomass production, and also that the amount of biomass produced in the AWW was greater compared to that produced in the F/2 synthetic medium (Figure 1A). This is in line with results of other authors confirming the relationship between the content of nutrients in wastewater and the increase in microalgal biomass $[33,34]$.
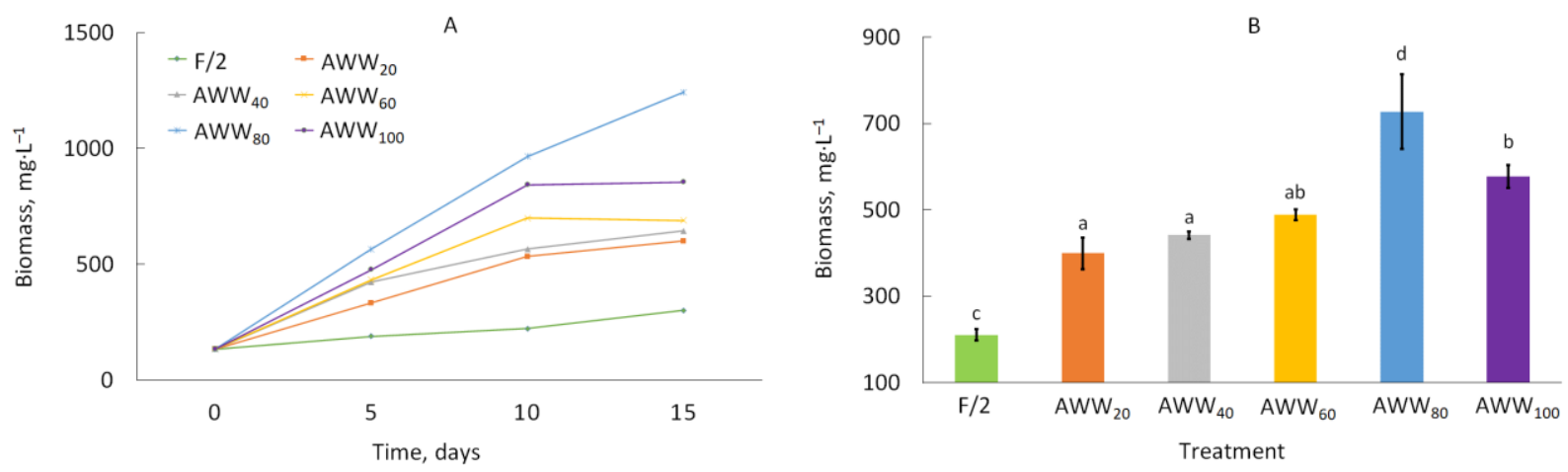

Figure 1. Dynamics of changes in biomass content (A) and the average biomass in culture (B).

The content of microalgal biomass is one of the most important parameters for evaluating the growth of microalgae. From the biomass content, it is possible to determine 
the time required to reach the maximum concentration of biomass as well as the growth phase [35]. At the beginning of the experiment, the biomass content was $133 \pm 9.43 \mathrm{mg} \cdot \mathrm{L}^{-1}$. In the following days, a linear growth with no growth inhibition phase was observed, which indicates that $C$. vulgaris can adapt and grow well in saline effluent from fish farming. Similar results were obtained in a study by Liu et al. [36], in which C. vulgaris was cultivated in AWW from a fishery and an increase in biomass was observed from the first days of measurement. In the present study, the largest amount of biomass after 15 days was determined in $\mathrm{AWW}_{80}\left(1244 \pm 62.85 \mathrm{mg} \cdot \mathrm{L}^{-1}\right)$, which indicates an increase of over $300 \%$ compared to the control treatment $(\mathrm{F} / 2)$. Similar positive results of microalgal cultivation and $C$. vulgaris biomass growth in pre-treated, nutrient-rich municipal sewage were also presented by Li et al. [37].

The average amount of biomass in this study ranged from $211 \pm 10.39 \mathrm{mg} \cdot \mathrm{L}^{-1}(\mathrm{~F} / 2)$ to $727 \pm 19.64 \mathrm{mg} \cdot \mathrm{L}^{-1}\left(\mathrm{AWW}_{80}\right)$, which is $345 \%$ of the values determined in the control treatment (Figure 1B). Hawrot-Paw et al. [38] cultivated Monoraphidium and achieved a significantly higher biomass content in AWW compared to the synthetic substrate F/2. FernándezLinares et al. [39] cultivated C. vulgaris in pre-treated municipal sewage and obtained an amount of biomass of $1575 \mathrm{mg} \cdot \mathrm{L}^{-1}$. Such a high biomass content was achieved due to the ability of the strain to adapt to the cultivation conditions (C. vulgaris strain was isolated from the environment of treated municipal wastewater). However, Guldhe et al. [40] presented different results on the use of AWW for the cultivation of Chlorella minutissima. The authors observed lower biomass productivity in AWW $\left(0.35 \mathrm{~g} \cdot \mathrm{L} \cdot \mathrm{day}^{-1}\right)$ than in synthetic BG11 medium $\left(0.57 \mathrm{~g} \cdot \mathrm{L} \cdot \mathrm{day}^{-1}\right)$. Mtaki et al. [41] added NPK fertilizer to AWW at a maximum dose of $1.0 \mathrm{~g} \cdot \mathrm{L}^{-1}$, which resulted in a significantly increased amount of $C$. vulgaris biomass compared to that obtained in synthetic bold basal medium (BBM).

The optical density of microalgal culture varied with the AWW dose (Figure 2A). Tossavainen et al. [42] and Hawrot-Paw et al. [38] observed a decrease in the content of microalgal biomass along with a decrease in nutrient contents in the culture medium. In the present study, the optical density, with the exception of $\mathrm{AWW}_{60}$, increased throughout the experiment. The mean optical density ranged from $0.246 \pm 0.00$ in $\mathrm{AWW}_{20}$ to $0.492 \pm 0.00$ in $\mathrm{AWW}_{60}$ (Figure 2B). The correlation coefficient between the OD680 values and the amount of biomass was $r=0.941$, which indicates a strong positive linear relationship.
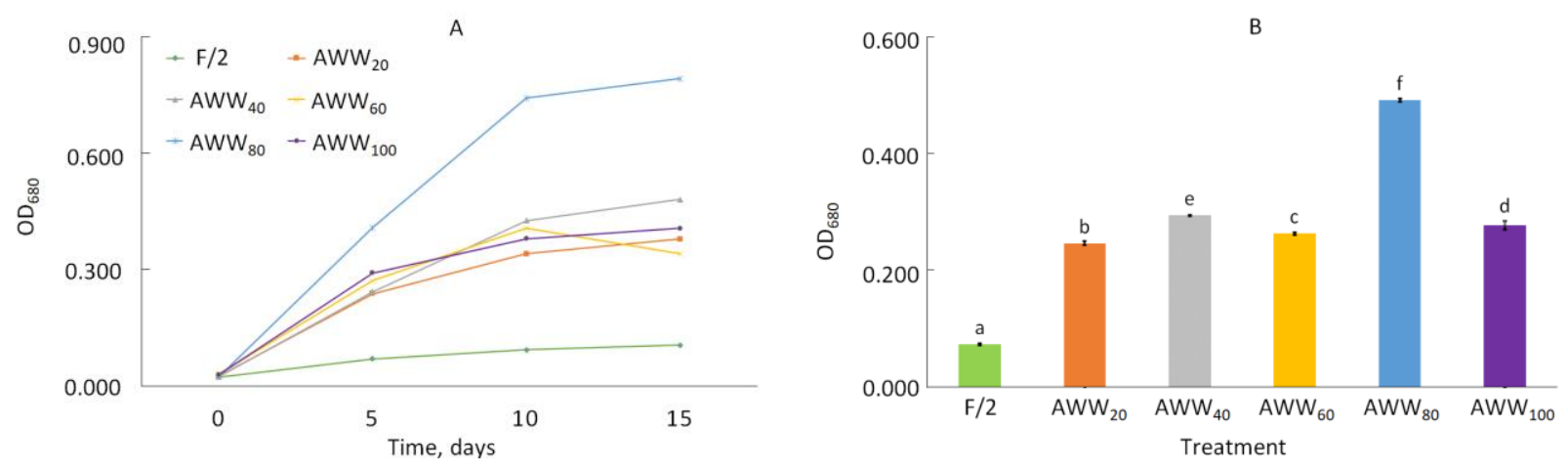

Figure 2. The dynamics of changes in optical density (A) and the average optical density in culture (B).

\subsection{Effect of Nitrogen Content on the Biomass and Lipid Content}

\subsubsection{Production of Biomass under Nutrient-Stress Condition}

Culture medium is one of the key factors influencing the production of microalgal biomass [43]. In industrial-scale production, the supply of an appropriate amount of nutrients constitutes an economic problem [44]. Therefore, the present study analyzed the possibility of using AWW rich in basic nutrients for biomass production and the impact of limiting the access to nutrients by AWW. It was observed that there was no phase delay in growth (Figure 3A), which clearly indicated that the strain adapted well to growth 
under conditions of limited nutrient access and salinity. In the initial phase of growth, on the fifth day of the experiment, the largest amount of biomass was recorded in $\mathrm{AWW}_{80}$ $\left(878 \pm 15.71 \mathrm{mg} \cdot \mathrm{L}^{-1}\right)$. This could be related to the method of inoculum preparation and the lack of the need to adapt to cultivation conditions. Similar results were obtained by Gao et al. [33] for the cultivation of C. vulgaris in photobioreactors using AWW in a batch culture. They obtained the maximum amount of biomass on the sixth day of the experiment $\left(0.07 \mathrm{~g} \cdot \mathrm{L}^{-1}\right)$. Tang et al. [45] reported that inhibition of microalgal growth could be related to a low content of nitrogen in the medium, which was fully taken up by algal cells in the initial growth phase. In the presented study, the start of the stationary growth phase, except in the case of $\mathrm{AWW}_{80}$, was observed after 10 days of cultivation. This could be related to the higher content of nutrients and their accumulation in algal cells. Algae can absorb excess nutrients and use them for growth in the later stages of cultivation [46]. In this study, the largest amount of biomass $\left(1045 \pm 31.43 \mathrm{mg} \cdot \mathrm{L}^{-1}\right)$ was determined in $\mathrm{AWW}_{60}$. The efficiency of microalgal biomass production is influenced by the presence of nitrogen [47]. The average amount of biomass ranged from $748 \pm 0.00 \mathrm{mg} \cdot \mathrm{L}^{-1}\left(\mathrm{AWW}_{20}\right)$ to $842 \pm 25.76 \mathrm{mg} \cdot \mathrm{L}^{-1}\left(\mathrm{AWW}_{60}\right)$ (Figure 3B). Ansari et al. [47] cultivated Scenedesmus obliquus, Chlorella sorokiniana and Ankistrodesmus falcatus in two media-BG11 and AWW-with lower nutrient content and observed a small amount of biomass in AWW. A similar dependence for C. minutissima was presented by Sánchez-García et al. [48], who found that a higher nitrogen dose in synthetic culture medium (BBM) caused an increase in biomass productivity. A higher content of microalgal biomass compared to the present study was observed by Tossavainen et al. [42]. The authors used pike perch AWW with a nitrogen content of $34 \mathrm{mg} \cdot \mathrm{L}^{-1}$ for the cultivation of Euglena gracilis and Selenastrum and obtained a maximum amount of algal biomass $\left(1.5 \mathrm{~g} \cdot \mathrm{L}^{-1}\right)$. This suggests that the biomass content may depend on the type of microalga, culture conditions, culture medium used and nutrient availability [49,50].

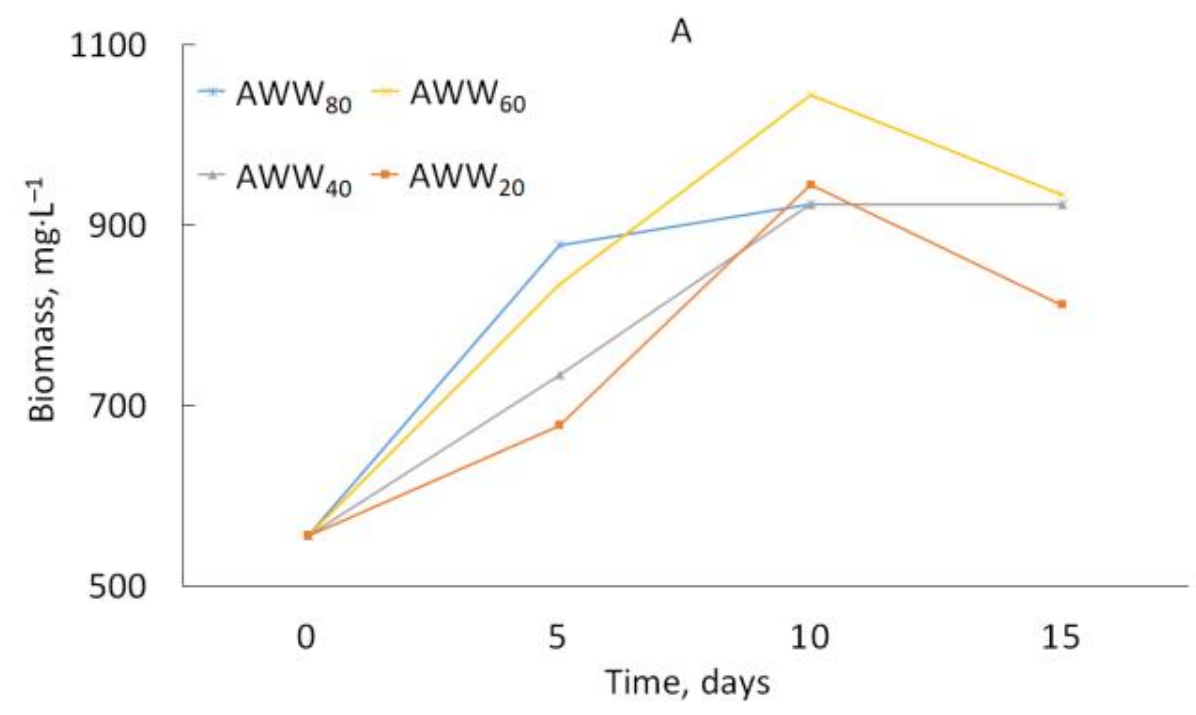

Figure 3. Cont. 


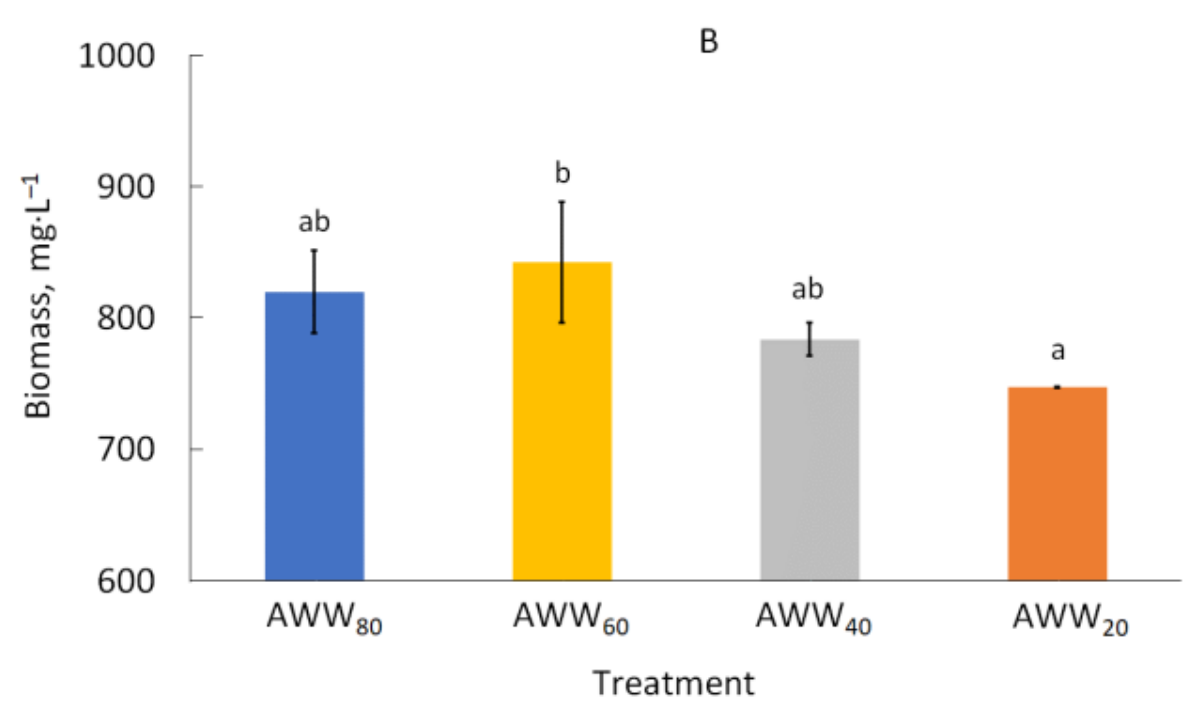

Figure 3. Dynamics of the growth of microalgal biomass (A) and the average amount of microalgal biomass (B).

\subsubsection{Optical Density of Microalgal Cultures}

In the present study, it was observed that the amount of biomass correlated with the optical density $(\mathrm{r}=0.841)$. The largest amount was obtained on the 15th day in $\mathrm{AWW}_{60}$ $(0.333 \pm 0.01)$, which is over $550 \%$ higher compared to the first day of measurement (Figure $4 \mathrm{~A})$. The average optical density ranged from $0.140 \pm 0.00\left(\mathrm{AWW}_{40}\right)$ to $0.201 \pm 0.00$ $\left(\mathrm{AWW}_{60}\right)$ (Figure $\left.4 \mathrm{~B}\right)$. Similar values of optical density (OD 0.304) were obtained by HawrotPaw et al. [34] during the cultivation of C. minutissima in the same type of salted AWW. This may be a result of different nutritional requirements of microalgae [51,52]. The increase in optical density with higher doses of AWW indicates that the high content of nutrients in the medium promotes the growth and development of algal cells. This was also confirmed by Bhatnagar et al. [53] when they cultivated microalgae in an organic enriched medium. Mtaki et al. [41] cultivated $C$. vulgaris and determined a much higher optical density value (OD 4.872), but in their study, AWW was supplemented with NPK.
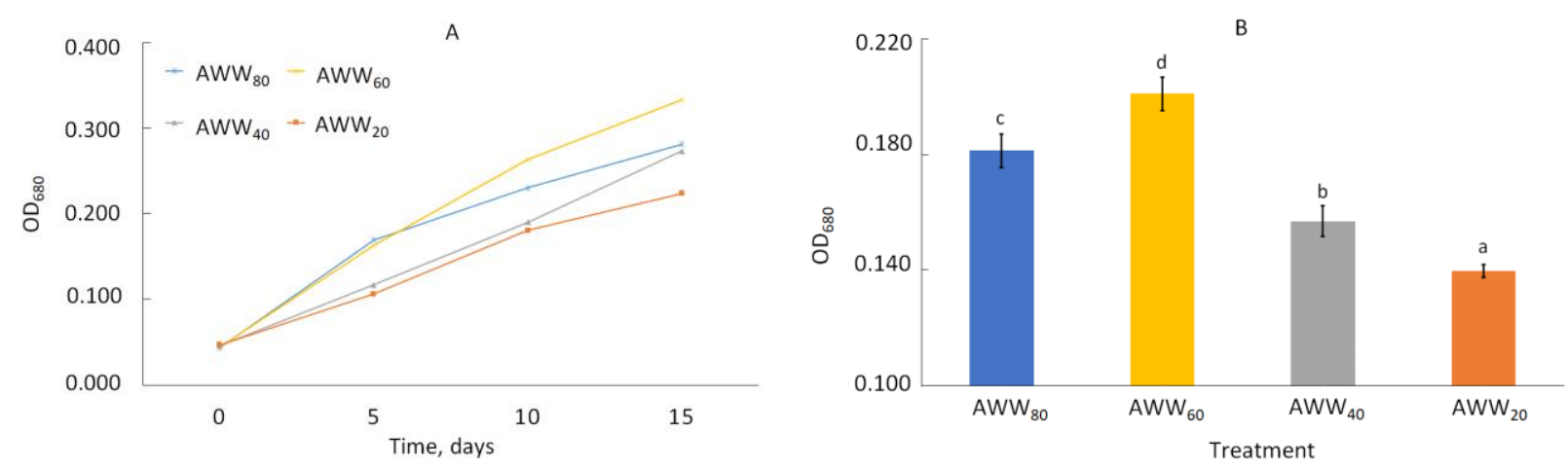

Figure 4. The dynamics of changes in optical density (A) and the average values of $\mathrm{OD}_{680}$ in culture (B).

\subsubsection{Lipid Accumulation under Nitrogen Limitation}

The mean lipid content of $C$. vugaris strains ranges from 14 to $22 \%$ [54,55], however, depending on the environment, it may vary from $5 \%$ to $58 \%$ [56]. In this study, the lipid content in biomass ranged from $5.75 \%\left(\mathrm{AWW}_{80}\right)$ to $11.81 \%\left(\mathrm{AWW}_{20}\right)$ (Figure 5). The effect on lipid accumulation in microalgal cells depends on the microalga species as well as the composition of the culture medium [57]. Wong et al. [58] analyzed the effect 
of the composition of 13 different culture media on the growth of $C$. vulgaris and lipid production. The authors observed that the maximum values for both these parameters were obtained with BBM. Synthetic culture media are expensive and can be replaced by AWW [41], which is not only cost-effective but also environmentally sustainable. The twofold increase in lipid content achieved in the present study was associated with nutrient stress caused by dilution of AWW. The nitrogen content in the culture medium ranged from $6.67 \pm 0.06 \mathrm{mg} \cdot \mathrm{L}^{-1}\left(\mathrm{AWW}_{20}\right)$ to $24.73 \pm 1.10 \mathrm{mg} \cdot \mathrm{L}^{-1}\left(\mathrm{AWW}_{80}\right)$. Under nitrogen-deficient conditions, the cellular metabolism of algae changes, resulting in the accumulation of lipids and starch in the biomass [59]. In a study by Pribyl et al. [60], the lipid productivity by C. vulgaris was higher at lower nitrate concentrations. Similar results were presented by Mutlu et al. [61] and Adenan et al. [62]. The authors noted that, under the nutritional stress caused by nitrogen limitation, lipid production significantly increased in C. vulgaris cells. The relationship between the increase in lipid content and nitrogen limitation was also reported by Ansari et al. [47]. The authors cultivated S. obliquus, C. sorokiniana and A. falcatus in aquaculture effluent with lower nitrogen content compared to the synthetic substrate and recorded increased lipid content for all algal species.

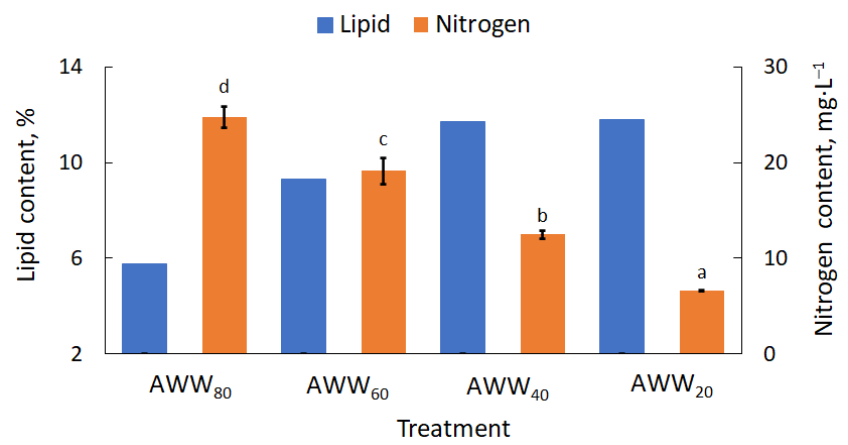

Figure 5. Nitrogen content in AWW and lipid content in microalgal biomass.

The results of this study thus showed a relationship between the nitrogen dose and lipid content in the microalgal biomass. With nitrogen deficiency, the metabolic pathway of carbon fixation changes from protein synthesis to lipid production [63]. It was found that the lower the initial content of nitrogen in the culture medium, the greater the amount of lipids in the biomass. The low lipid content observed in $\mathrm{AWW}_{80}$ could be caused by the intense growth of microalgae. A distinct stationary growth phase was not noted in the study, although it is in this phase that microalgae form lipids as an energy reserve [64]. This has been confirmed by other authors $[65,66]$ for both marine and freshwater strains. A much higher lipid accumulation was determined by Rai et al. [67] during the cultivation of $C$. vulgaris in saline medium. While maintaining the nitrogen content at a level of $<5 \mathrm{mg} \cdot \mathrm{L}^{-1}$, these authors recorded a lipid content of $40 \%$. An additional factor stimulating lipid accumulation in microalgal cells may be the salinity level. This was supported by the results of Mirizadeh et al. [68], who analyzed the effect of introducing $\mathrm{NaCl}$ into the culture medium at doses ranging from 5 to $30 \mathrm{~g} \mathrm{~L}^{-1}$. The authors found an increase in lipid content in the biomass of $C$. vulgaris with increasing concentration of $\mathrm{NaCl}$ up to $25 \mathrm{~g} \mathrm{~L}^{-1}$ (about 1.5-fold higher than without salt). In the study by Hawrot-Paw et al. [34], the lipid content in the biomass of $C$. minutissima cultured on saline salmon AWW decreased while the biomass content increased compared to the synthetic F/ 2 medium. The differences between the nutrient content of the medium and the amount of lipids in the cells are related to the type of microalga. The division of stress into three categories, from low to high, is conceptually adopted, where the increase in lipids exceeds the decrease in biomass content, the decrease in growth exceeds the increase in lipids, and the increase in lipid content is compensated by the decrease in growth [11]. 


\subsubsection{Changes in $\mathrm{PH}$ during Microalga Cultivation}

The $\mathrm{pH}$ of the culture medium affects the proper cell development, availability of nutrients and ability of algal cells to carry out photosynthesis [69]. In the present study, C. vulgaris was cultivated under uncontrolled $\mathrm{pH}$ conditions. At the start of the experiment, the $\mathrm{pH}$ of the medium ranged from $8.3\left(\mathrm{AWW}_{80}\right)$ to $8.5\left(\mathrm{AWW}_{20}\right)$ (Figure 6). After five days of cultivation, an increase to a value of 9 was recorded, which was related to $\mathrm{CO}_{2}$ fixation [70] or the passage of air through the microalgal cultures and dissipation of carbon dioxide by agitation [71]. After 15 days, the $\mathrm{pH}$ of the medium was in the range of 8.6-8.9. This is considered as the optimal range for algae, which is also supported by Rai and Rajashekhar [67], who indicated that the optimal $\mathrm{pH}$ for algae ranges from 6 to 10 . Scherholz and Curtis [72] described that the $\mathrm{pH}$ of the culture medium may be related to the influence of ammonium on the transport and reduction of nitrates.

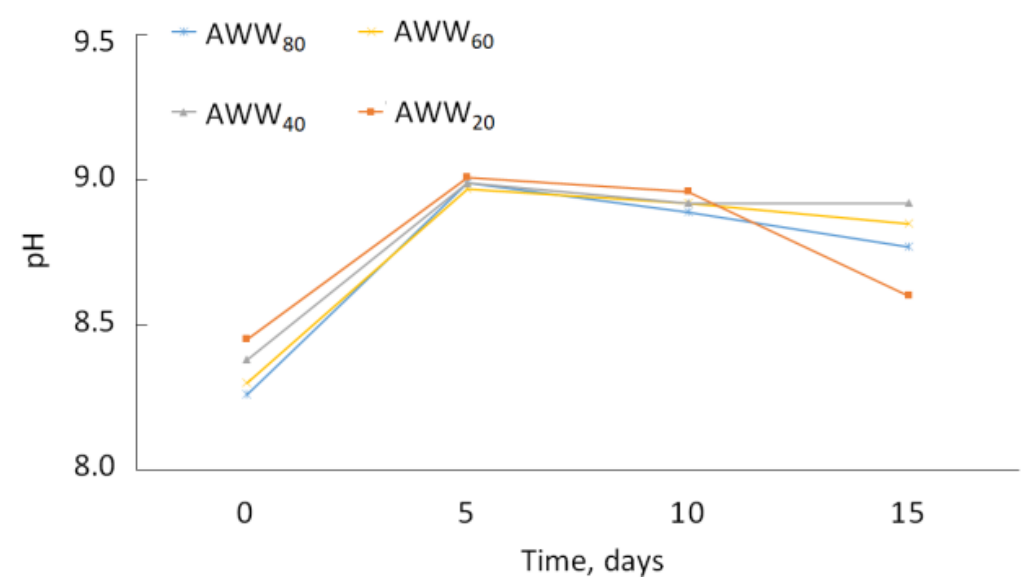

Figure 6. The dynamics of $\mathrm{pH}$ changes in culture medium.

\subsubsection{Chlorophyll A Content in Microalgal Biomass}

The initial content of chlorophyll a in microalgal cells was determined to be $50 \pm 5.03 \mathrm{mg} \cdot \mathrm{m}^{-3}$ (Figure 7A). The highest content of pigment $\left(328 \pm 21.95 \mathrm{mg} \cdot \mathrm{m}^{-3}\right)$ was observed in $\mathrm{AWW}_{20}$ after 10 days of cultivation. Depending on the dose of AWW, the mean chlorophyll a content ranged from $160 \pm 17.84 \mathrm{mg} \cdot \mathrm{m}^{-3}\left(\mathrm{AWW}_{80}\right)$ to $206 \pm 11.33 \mathrm{mg} \cdot \mathrm{m}^{-3}$ $\left(\mathrm{AWW}_{20}\right)$ (Figure $\left.7 \mathrm{~B}\right)$. The content of chlorophyll a in microalgal cells decreased with an increase in the amount of nitrogen in the medium. Contrasting results were reported by Ördög et al. [73] in their study on Chlorella minutissima, in which the content of chlorophyll increased after the addition of nitrogen. Similarly, Li et al. [74] observed a decrease in chlorophyll content in Neochloris oleoabundans cells cultivated in medium with lower nitrogen content and suggested that this may be related to the utilization of nitrogen compounds in chlorophyll by microalgae. The availability of nutrients affects the concentration of chlorophyll in microalgal cells, but it varies depending on the species [75]. The increase in pigment content in diluted AWW could be due to a higher intensity of photosynthesis caused by better light penetration into cells with lower biomass. The relationship between the increase in biomass and the decrease in chlorophyll in C. vulgaris cells was also presented by Mohsenpour et al. [76]. 

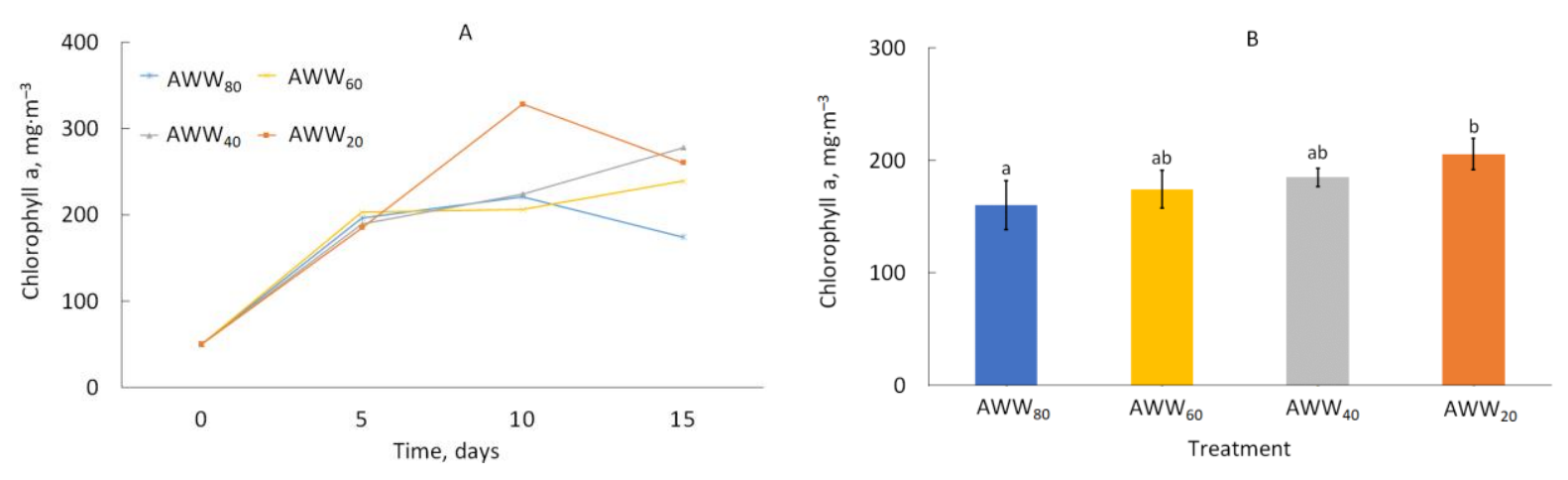

Figure 7. The dynamics of changes in the amount of chlorophyll a (A) and the average values of chlorophyll in culture (B).

\section{Materials and Methods}

\subsection{Microalgal Culture}

Green algae (C. vulgaris (BA 002)) were obtained from the Culture Collection of Baltic Algae (University of Gdansk, Gdańsk, Poland). The microalgae were cultured in Guillard's (F/2) Marine Enrichment liquid medium [77] at a temperature of $4{ }^{\circ} \mathrm{C}$ under lighting with a light-emitting diode (LED; $12 / 12 \mathrm{~h}$ light:dark cycle). The liquid medium had the following composition $\left(\mathrm{g} \cdot \mathrm{L}^{-1}\right)$ : $\mathrm{NaNO}_{3}-0.075 \mathrm{~g} ; \mathrm{NaH}_{2} \mathrm{PO}_{4} \cdot 2 \mathrm{H}_{2} \mathrm{O}-0.00565 \mathrm{~g}$; stock solution of trace elements- $1 \mathrm{~mL} \cdot \mathrm{L}^{-1}\left(\mathrm{Na}_{2}\right.$ EDTA $4.16 \mathrm{~g}, \mathrm{FeCl}_{3} 6 \mathrm{H}_{2} \mathrm{O} 3.15 \mathrm{~g}, \mathrm{CuSO}_{4} 5 \mathrm{H}_{2} \mathrm{O} 0.01 \mathrm{~g}, \mathrm{ZnSO}_{4}$ $7 \mathrm{H}_{2} \mathrm{O} 0.022 \mathrm{~g}, \mathrm{CoCl}_{2} 6 \mathrm{H}_{2} \mathrm{O} 0.01 \mathrm{~g}, \mathrm{MnCl}_{2} 4 \mathrm{H}_{2} \mathrm{O} 0.18 \mathrm{~g}$ and $\mathrm{NaMoO}_{4} 2 \mathrm{H}_{2} \mathrm{O} 0.18 \mathrm{~g}$ ) and stock solution of vitamin mix $-1 \mathrm{~mL} \cdot \mathrm{L}^{-1}$ (cyanocobalamin (vitamin B12) $0.0005 \mathrm{~g}$, thiamine $\mathrm{HCl}$ (vitamin B1) $0.1 \mathrm{~g}$, biotin $0.0005 \mathrm{~g}$ ).

\subsection{Aquaculture Wastewater}

AWW was obtained from Jurassic Salmon (Karnice, Poland), an ecological closedcircuit salmon farm. The average content of nitrogen in the wastewater was $31.8 \mathrm{mg} \cdot \mathrm{L}^{-1}$, while the content of phosphorus was $1.1 \mathrm{mg} \cdot \mathrm{L}^{-1}$ at a salinity level of $10 \%$. AWW was collected from a storage tank and stored in a refrigerator at a temperature of $4{ }^{\circ} \mathrm{C}$. Before use, the wastewater was filtered twice through membrane filters to remove solid impurities, and then filters with a pore diameter of $1.2 \mu \mathrm{m}$. Finally, the wastewater was sterilized with UV-C (13 W waterproof lamp, $15 \mathrm{~min})$.

\subsection{Experimental Setup}

The experiment was divided into two stages. In the first stage, the influence of the AWW dose on the content of microalgal biomass was determined. Vertical tubular photobioreactors with a capacity of $2.5 \mathrm{dm}^{3}$ (Aqua Medic, Bissendorf, Germany) were used for the experiment. In these photobioreactors, $2 \mathrm{dm}^{3}$ of medium and $200 \mathrm{~cm}^{3}$ of a 10-day inoculum of microalgae (C. vulgaris) were added. AWW was used at doses of 20\%, 40\%, $60 \%, 80 \%$ and $100 \%$. Commercial $\mathrm{F} / 2$ culture medium was used as a control treatment in the experiment. All the photobioreactors were aerated with a $25 \mathrm{~W}$ pump (Aqua Medic, Bissendorf, Germany) at a capacity of $0.9 \mathrm{~m}^{-3} \cdot \mathrm{h}^{-1}$, which allowed us to introduce carbon dioxide and prevent biomass sedimentation. The $\mathrm{pH}$ of the medium was adjusted to 7 by adding $1 \mathrm{~N} \mathrm{NaOH}$. The cultures were illuminated with LEDs: white, red (wavelength 600-700 nm, light intensity of $9.45 \mu \mathrm{mol} \mathrm{s}{ }^{-1}$ ) and blue (wavelength 400-500 nm, light intensity of $\left.2.25 \mu \mathrm{mol} \cdot \mathrm{s}^{-1}\right)$. Lighting was maintained on an 18/6 h light:dark cycle. The total LED intensity was $13.5 \mu_{\mathrm{mol} \mathrm{s}}^{-1}$ (HOLDBOX, Żabia Wola, Poland). The experiment was carried out for 15 days, and then the amount of biomass and optical density of cultures were determined.

In the second stage of the experiment, the influence of nutrient stress on the amount of C. vulgaris biomass and on the content of lipids in biomass was assessed. Additionally, optical density and chlorophyll a content were calculated. At this stage, the biological 
material that was obtained under optimal growth conditions for algal biomass was used as an inoculum (for the AWW dose). The experiment was carried out in vertical tubular photobioreactors with a capacity of $14 \mathrm{dm}^{3}$, with $10.8 \mathrm{dm}^{3}$ of AWW (doses of $20 \%, 40 \%$, $60 \%$ and $80 \%$ ) and $1.2 \mathrm{dm}^{3}$ of C. vulgaris inoculum. The cultures were illuminated with LED light, and aerated using a pump with a power of $12 \mathrm{~W}$ at a capacity of $14 \mathrm{~L} \cdot \mathrm{min}^{-1}$. The experiment was carried out as a batch culture for 15 days.

\subsection{Analytical Methods}

\subsubsection{Biomass Quantification}

The dry weight of microalgae was determined by a gravimetric method described by Ratha et al. [78] with modification [79]. The amount of biomass was estimated using a moisture analyzer (AXIS ATS, Gdańsk, Poland). The results are presented in $\mathrm{mg} \cdot \mathrm{L}^{-1}$.

The optical density of microalgal cultures was measured using a spectrophotometer (EMCO, Warszawa, Poland) at a wavelength of $\lambda=680$.

\subsubsection{Pigment Extraction and Analysis}

The content of chlorophyll a in microalgal cells was measured according to PN86 C-05560/02 standards [80]. Briefly, the algal biomass was concentrated by vacuum filtration on a glass fiber filter, and then the chlorophyll pigment was extracted with a solution of $90 \%$ acetone. Absorbance was measured at a wavelength of $\lambda=665 \mathrm{~nm}$ using a spectrophotometer (EMCO, Warszawa, Poland). The results are presented in $\mathrm{mg} \mathrm{m}^{-3}$.

\subsubsection{Determination of $\mathrm{PH}$}

The $\mathrm{pH}$ of the culture medium was measured using a CI-316 microcomputer $\mathrm{pH}$-meter (Conrad Electronic SE, Hirschau, Germany).

\subsubsection{Lipids Extraction and Determination}

The lipid content of the biomass was determined by Soxhlet extraction with hexane using the modified method of Shin et al. [81]. The analyses were carried out after 15 days of cultivation. Following sedimentation, the biomass was dried in a laboratory dryer (WAMED, Warszawa, Poland) at $70{ }^{\circ} \mathrm{C}$ for $24 \mathrm{~h}$. Then, $0.5 \mathrm{~g}$ of the dried sample were transferred to a cellulose casing and extracted in a Soxhlet apparatus (Labmed HK, Łódź, Poland) with hexane for $4 \mathrm{~h}$ ( 20 cycles per hour). The lipid content of the sample was determined using the following formula (1):

$$
\mathrm{LC}=\left(\frac{\mathrm{mL}}{\mathrm{mDAB}}\right) \cdot 100
$$

where LC is the lipid content, $\mathrm{mL}$ is the mass of lipids (g) and mDAB is the mass of dry microalgal biomass $(\mathrm{g})$.

\subsubsection{Determination of Total Nitrogen Content}

The total nitrogen in the culture medium was determined using the spectrophotometric method according to PN-EN ISO 11905-1: 2001 standards [82]. The obtained results were converted into $\mathrm{mg} \cdot \mathrm{L}^{-1}$. Nitrogen analyses were also performed once at the beginning of the study.

\subsection{Statistical Analysis}

All analyses, except for lipid content, were performed in triplicate. The results were statistically analyzed using a computer program for Windows (Statistica version 13.3, 2016; Dell Inc., Tulsa, OK, USA). An analysis of variance was performed, followed by Tukey's significance tests at a level of $p \leq 0.05$. In addition, Pearson's linear correlation coefficient (r) and standard deviations were determined. 


\section{Conclusions}

This study confirmed the possibility of using saline wastewater from salmon farming for the production of $C$. vulgaris biomass, which will allow for the simultaneous removal of nutrients from AWW. The content of nutrients in the wastewater originating from fisheries was identified as an important parameter influencing the amount of biomass produced. The largest amount of biomass $\left(727 \pm 19.64 \mathrm{mg} \cdot \mathrm{L}^{-1}\right)$ and the highest values of optical density $(0.492 \pm 0.00)$ were obtained at the higher doses of AWW $(80 \%)$. On the other hand, the highest content of chlorophyll was determined in $\mathrm{AWW}_{20}$. Due to the limited access to nitrogen, the lipid content in the biomass increased. The highest lipid content $(11.81 \%)$ was determined in the most diluted culture medium $\left(A W W_{20}\right)$, in which the initial nitrogen content was $6.67 \pm 0.06 \mathrm{mg} \cdot \mathrm{L}^{-1}$. Considering that algal biomass can be used for energy purposes, the cost of the growth medium, which accounts for a significant part of the total production costs, is important for advanced biofuel production.

Author Contributions: Conceptualization, P.R. and M.H.-P.; methodology, M.H.-P.; validation, P.R. and M.H.-P; formal analysis, P.R. and M.H.-P.; investigation, P.R.; writing-original draft preparation, P.R. and M.H.-P.; writing-review and editing, P.R. and M.H.-P.; visualization, P.R. and M.H.-P.; supervision, M.H.-P. All authors have read and agreed to the published version of the manuscript.

Funding: This research received no external funding.

Data Availability Statement: The data presented in this study are available on request from the corresponding author.

Conflicts of Interest: The authors declare no conflict of interest.

\section{References}

1. Zhang, Z. Comparisons of various absorbent effects on carbon dioxide capture in membrane gas absorption (MGA) process. J. Nat. Gas Sci. Eng. 2016, 31, 589-595. [CrossRef]

2. Chisti, Y. Biodiesel from microalgae. Biotechnol. Adv. 2007, 25, 294-306. [CrossRef]

3. Arumugam, M.; Agarwal, A.; Arya, M.C.; Ahmed, Z. Influence of nitrogen sources on biomass productivity of microalgae Scenedesmus bijugatus. Bioresour. Technol. 2013, 131, 246-249. [CrossRef]

4. John, R.P.; Anisha, G.S.; Nampoothiri, K.M.; Pandey, A. Micro and macroalgal biomass: A renewable source for bioethanol. Bioresour. Technol. 2011, 102, 186-193. [CrossRef]

5. Ho, S.H.; Ye, X.; Hasunuma, T.; Chang, J.S.; Kondo, A. Perspectives on engineering strategies for improving biofuels production from microalgae-A critical review. Biotechnol. Adv. 2014, 32, 1448-1459. [CrossRef] [PubMed]

6. Zheng, Y.P.; Huang, Y.; Liao, Q.; Fu, Q.; Xia, A. Effect of wettability on the growth of Scenedesmus obliquus biofilm attached on glass surface coated with polytetrafluoroethylene emulsion. Int. J. Hydrog. Energy 2016, 41, 21728-21735. [CrossRef]

7. Babu, A.; Wu, X.; Kabra, A.N.; Kim, D.P. Cultivation an indigenous Chlorella sorokiniana with phytohormones for biomass and lipid production under N-limitations. Algal Res. 2017, 23, 178-185. [CrossRef]

8. Singh, P.; Kumari, S.; Guldhe, A.; Misra, R.; Rawat, I.; Bux, F. Trends and novel strategies for enhancing lipid accumulation and quality in microalgae. Renew. Sust. Energ. Rev. 2016, 55, 1-16. [CrossRef]

9. Li, T.; Xu, J.; Gao, B.; Xiang, W.Z.; Zhang, C. Morphology, growth, biochemical composition and photosynthetic performance of Chlorella vulgaris (Trebouxiophyceae) under low and high nitrogen supplies. Algal Res. 2016, 16, 481-491. [CrossRef]

10. Sharma, K.K.; Schuhmann, H.; Schenk, P.M. High Lipid Induction in Microalgae for Biodiesel Production. Energies 2012, 5, 1532-1553. [CrossRef]

11. Piligaev, A.V.; Sorokina, K.N.; Samoylova, Y.V.; Parmon, V.N. Production of Microalgal Biomass with High Lipid Content and Their Catalytic Processing Into Biodiesel: A Review. Catal. Ind. 2019, 11, 349-359. [CrossRef]

12. Khan, M.I.; Shin, J.H.; Kim, J.D. The promising future of microalgae: Current status, challenges, and optimization of a sustainable and renewable industry for biofuels, feed, and other products. Microb. Cell Fact. 2018, 17, 36. [CrossRef] [PubMed]

13. Morgan-Kiss, R.M.; Priscu, J.C.; Pocock, T.; Gudynaite-Savitch, L.; Huner, N.P.A. Adaptation and acclimation of photosynthetic microorganisms to permanently cold environments. Microbiol. Mol. Biol. Rev. 2006, 70, 222-252. [CrossRef] [PubMed]

14. Metsoviti, M.N.; Papapolymerou, G.; Karapanagiotidis, I.T.; Katsoulas, N. Effect of Light Intensity and Quality on Growth Rate and Composition of Chlorella vulgaris. Plants 2020, 9, 31. [CrossRef] [PubMed]

15. Varshney, P.; Beardall, J.; Bhattacharya, S.; Wangikar, P.P. Effect of elevated carbon dioxide and nitric oxide on the physiologicalresponses of two green algae, Asterarcys quadricellulare and Chlorella sorokiniana. J. Appl. Phycol. 2020, 32, 189-204. [CrossRef]

16. Mishra, S.; Liu, Y.-J.; Chen, C.-S.; Yao, D.-J. An Easily Accessible Microfluidic Chip for High-Throughput Microalgae Screening for Biofuel Production. Energies 2021, 14, 1817. [CrossRef] 
17. Takagi, M.; Yoshida, T. Effect of salt concentration on intracellular accumulation of lipids and triacylglyceride in marine microalgae Dunaliella cells. J. Biosci. Bioeng. 2006, 101, 223-226. [CrossRef]

18. An, M.; Gao, L.; Zhao, W.; Chen, W.; Li, M. Effects of Nitrogen Forms and Supply Mode on Lipid Production of Microalga Scenedesmus Obliq. Energies 2020, 13, 697. [CrossRef]

19. Tang, D.; Han, W.; Li, P.; Miao, X.; Zhong, J. $\mathrm{CO}_{2}$ biofixation and fatty acid composition of Scenedesmus obliquus and Chlorella pyrenoidosa in response to different $\mathrm{CO}_{2}$ levels. Bioresour. Technol. 2011, 102, 3071-3076. [CrossRef]

20. Xu, N.; Zhang, X.; Fan, X.; Han, L.; Zeng, C. Effects of nitrogen source and concentration on growth rate and fatty acid composition of Ellipsoidion sp. (Eustigmatophyta). J. Appl. Phycol. 2001, 13, 463-469. [CrossRef]

21. Yang, L.; Chen, J.; Qin, S.; Zeng, M.; Jiang, Y.; Hu, L.; Xiao, P.; Hao, W.; Hu, Z.; Lei, A.; et al. Growth and lipid accumulation by different nutrients in the microalga Chlamydomonas reinhardtii. Biotechnol. Biofuels 2008, 11, 40. [CrossRef] [PubMed]

22. Vooren, G.V.; Grand, F.L.; Legrand, J.; Cuiné, S.; Peltier, G.; Pruvost, J. Investigation of fatty acids accumulation in Nannochloropsis oculata for biodiesel application. Bioresour. Technol. 2012, 124, 421-432. [CrossRef] [PubMed]

23. Rai, M.P.; Gautom, T.; Sharma, N. Effect of salinity, $\mathrm{pH}$, light intensity on growth and lipid production of microalgae for bioenergy application. J. Biol. Sci. 2015, 15, 260-267. [CrossRef]

24. Adams, C.; Godfrey, V.; Wahlen, B.; Seefeldt, L.; Bugbee, B. Understanding precision nitrogen stress to optimize the growth and lipid content tradeoff in oleaginous green microalgae. Biores. Technol. 2013, 131, 188-194. [CrossRef]

25. Kozieł, W.; Włodarczyk, T. Glony-produkcja biomasy. Acta Agroph. 2011, 17, 105-116.

26. Makowska, M.; Dziosa, K. Wytwarzanie biomasy mikroalg w warunkach laboratoryjnych. Przem. Chem. 2015, 94, 982-985.

27. Loera-Quezada, M.M.; Angeles, G.; Olguín, E.J. Effect of irradiance on the cell density, size and lipid accumulation of Neochloris oleoabundans. Rev. Latinoam. Biotechnol. Amb. Algal. 2011, 2, 81-92.

28. Rendón, L.; Ramírez, M.; Vélez, Y. Microalgas para la Industria Alimenticia; Universidad Pontifica Bolivariana: Medellín, Colombia, 2015.

29. Escapa, C.; García, A. Eliminación de nutrientes en aguas residuales y biofijación de $\mathrm{CO}_{2}$ mediante el cultivo de microalgas. Sci. Soc. Galicia 2013, 2, 63-76.

30. Abdel-Raouf, N.; Al-Homaidan, A.; Ibraheem, I.B.M. Microalgae and wastewater treatment. Saudi J. Biol. Sci. 2012, 19, 257-275. [CrossRef]

31. Markou, G.; Georgakakis, D. Cultivation of filamentous cyanobacteria (blue green algae) in agro-industrial wastes and wastewaters: A review. Appl. Energy 2011, 88, 3389-3401. [CrossRef]

32. Demirbas, A.; Demirbas, M.F. Importance of Algae Oil as a Source of Biodiesel. Energy Convers. Manag. 2011, 52, 163-170. [CrossRef]

33. Gao, F.; Li, C.; Yang, Z.H.; Zeng, G.M.; Feng, L.J.; Liu, J.Z.; Liu, M.; Cai, H.W. Continuous microalgae cultivation in aquaculture wastewater by a membrane photobioreactor for biomass production and nutrients removal. Ecol. Eng. 2016, 92, 55-61. [CrossRef]

34. Hawrot-Paw, M.; Koniuszy, A.; Gałczyńska, M.; Zając, G.; Szyszlak-Bargłowicz, J. Production of Microalgal Biomass Using Aquaculture Wastewater as Growth Medium. Water 2019, 12, 106. [CrossRef]

35. Ruiz, J.; Álvarez-Díaz, P.D.; Arbib, Z.; Garrido-Pérez, C.; Barragán, J.; Perales, J.A. Performance of a flat panel reactor in the continuous culture of microalgae in urban wastewater: Prediction from a batch experiment. Bioresour. Technol. 2013, 127, 456-463. [CrossRef] [PubMed]

36. Liu, Y.; Lv, J.; Feng, J.; Liu, Q.; Nan, F.; Xie, S. Treatment of real aquaculture wastewater from a fishery utilizing phytoremediation with microalgae. J. Chem. Technol. Biotechnol. 2019, 94, 900-910. [CrossRef]

37. Li, Y.; Zhou, W.; Hu, B.; Min, M.; Chen, P.; Ruan, R.R. Integration of algae cultivation as biodiesel production feedstock with municipal wastewater treatment: Strains screening and significance evaluation of environmental factors. Bioresour. Technol. 2011, 102, 10861-10867. [CrossRef]

38. Hawrot-Paw, M.; Koniuszy, A.; Gałczyńska, M. Sustainable Production of Monoraphidium Microalgae Biomass as a Source of Bioenergy. Energies 2020, 13, 5975. [CrossRef]

39. Fernández-Linares, L.C.; Guerrero-Barajas, C.; Durán-Páramo, E.; Badillo Corona, J.A. Assessment of Chlorella vulgaris and indigenous microalgae biomass with treated wastewater as growth culture medium. Bioresour. Technol. 2017, 244, 400-406. [CrossRef]

40. Guldhe, A.; Ansari, F.A.; Singh, P.; Bux, F. Heterotrophic cultivation of microalgae using aquaculture wastewater: A biorefinery concept for biomass production and nutrient remediation. Ecol. Eng. 2017, 99, 47-53. [CrossRef]

41. Mtaki, K.; Kyewalyanga, M.S.; Mtolera, M.S.P. Supplementing wastewater with NPK fertilizer as a cheap source of nutrients in cultivating live food (Chlorella vulgaris). Ann. Microbiol. 2021, 71. [CrossRef]

42. Tossavainen, M.; Lahti, K.; Edelmann, M.; Eskola, R.; Lampi, A.-M.; Piironen, V.; Korvonen, P.; Ojala, A.; Romantschuk, M. Integrated utilization of microalgae cultured in aquaculture wastewater: Wastewater treatment and production of valuable fatty acids and tocopherols. J. Appl. Phycol. 2019, 31, 1753-1763. [CrossRef]

43. Mahmood, A.K.H.; Mohsin, K.E. Experimental study for commercial fertilizer NPK (20:20:20+TE N: P: K) in microalgae cultivation at different aeration periods. Iraqi J. Chem. Pet. Eng. 2017, 18, 99-110.

44. Nayak, M.; Karemore, A.; Sen, R. Performance evaluation of microalgae for concomitant wastewater bioremediation, $\mathrm{CO}_{2}$ biofixation and lipid biosynthesis for biodiesel application. Algal Res. 2016, 16, 216-223. [CrossRef]

45. Tang, H.; Chen, M.; Simon Ng, K.Y.; Salley, S.O. Continuous microalgae cultivation in a photobioreactor. Biotechnol. Bioeng. 2012, 109, 2468-2474. [CrossRef] [PubMed] 
46. Zhu, S.; Wang, Y.; Xu, J.; Shang, C.; Wang, Z.; Xu, J.; Yuan, Z. Luxury uptake of phosphorus changes the accumulation of starch and lipid in Chlorella sp. under nitrogen depletion. Bioresour. Technol. 2015, 198, 165-171. [CrossRef] [PubMed]

47. Ansari, F.A.; Singh, P.; Guldhe, A.; Bux, F. Microalgal cultivation using aquaculture wastewater: Integrated biomass generation and nutrient remediation. Algal Res. 2017, 21, 169-177. [CrossRef]

48. Sánchez-García, D.; Resendiz-Isidro, A.; Villegas-Garrido, T.L.; Flores-Ortiz, C.M.; Chávez-Gómez, B.; Cristiani-Urbi, E. Effect of nitrate on lipid production by T. suecica, M. contortum, and C. minutissima. Cent. Eur. J. Biol. 2013, 8, 578-590. [CrossRef]

49. Do, J.M.; Jo, S.W.; Kim, I.S.; Na, H.; Lee, J.H.; Kim, H.S.; Yoon, H.S. A feasibility study of wastewater treatment using domestic microalgae and analysis of biomass for potential applications. Water 2019, 11, 2294. [CrossRef]

50. Sacristán de Alva, M.; Luna-Pabello, V.M.; Cadena, E.; Ortiz, E. Green microalgae Scenedesmus acutus grown on municipal wastewater to couple nutrient removal with lipid accumulation for biodiesel production. Bioresour. Technol. 2013, 146, 744-748. [CrossRef]

51. Cai, T.; Park, S.Y.; Li, Y. Nutrient recovery from wastewater streams by microalgae: Status and prospects. Renew. Sustain. Energy Rev. 2013, 19, 360-369. [CrossRef]

52. Lu, Q.; Zhou, W.; Min, M.; Ma, X.; Ceria Chandra, Y.T.T.D.; Yiwei, M.; Zheng, H.; Cheng, S.; Griffith, R.; Chen, P.; et al. Growing Chlorella sp. on meat processing wastewater for nutrient removal and biomass production. Bioresour. Technol. 2015, 198, 189-197. [CrossRef]

53. Bhatnagar, A.; Chinnasamy, S.; Singh, M. Renewable biomass production by mixotrophic algae in the presence of various carbon sources and wastewaters. Appl. Energy 2011, 88, 3425-3431. [CrossRef]

54. Kim, J.; Lingaraju, B.P.; Rheaume, R.; Lee, J.Y.; Siddiqui, K.F. Removal of ammonia from wastewater effluent by Chlorella vulgaris. Tsinghua Sci. Technol. 2010, 15, 391-396. [CrossRef]

55. Mata, T.M.; Martins, A.A.; Caetano, N.S. Microalgae for biodiesel production and other applications: A review. Renew Sustain. Energy Rev. 2010, 14, 217-232. [CrossRef]

56. Ru, I.T.K.; Sung, Y.Y.; Jusoh, M.; Wahid, M.E.A.; Nagappan, T. Chlorella vulgaris: A perspective on its potential for combining high biomass with high value bioproducts. Appl. Phycol. 2020, 1, 2-11. [CrossRef]

57. Chen, C.Y.; Yeh, K.L.; Aisyah, R.; Lee, D.J.; Chang, J.S. Cultivation, photobioreactor design and harvesting of microalgae for biodiesel production: A critical review. Bioresour. Technol. 2011, 102, 71-81. [CrossRef]

58. Wong, Y.K.; Ho, Y.H.; Ho, K.C.; Leung, H.M.; Yung, K.K.L. Growth medium screening for Chlorella vulgaris growth and lipid production. J. Aquac. Mar. Biol. 2017, 6, 00143. [CrossRef]

59. Geider, R.; La Roche, J. Redfield revisited: Variability of C:N:P in marine microalgae and its biochemical basis. Eur. J. Phycol. 2002, 37, 1-17. [CrossRef]

60. Pribyl, P.; Cepak, V.; Zachleder, V. Production of lipids in 10 strains of Chlorella and Parachlorella, and enhanced lipid productivity in Chlorella vulgaris. Appl. Microbiol. Biotechnol. 2012, 94, 549-561. [CrossRef] [PubMed]

61. Mutlu, Y.B.; Isik, O.; Uslu, L.; Koc, K.; Durmaz, Y. The effects of nitrogen and phosphorus deficiencies and nitrite addition on the lipid content of Chlorella vulgaris (Chlorophyceae). Afr. J. Biotechnol. 2011, 10, 453-456.

62. Adenan, N.S.; Yusoff, F.M.; Medipally, S.R.; Shariff, M. Enhancement of lipid production in two marine microalgae under different levels of nitrogen and phosphorus deficiency. J. Environ. Biol. 2016, 37, 669-676. [PubMed]

63. Chandra, R.; Rohit, M.V.; Swamy, Y.V.; Venkata Mohan, S. Regulatory function of organic carbon supplementation on biodiesel production during growth and nutrient stress phases of mixotrophic microalgae cultivation. Bioresour. Technol. 2014, 165, 279-287. [CrossRef] [PubMed]

64. Sarat Chandra, T.; Deepak, R.S.; Maneesh Kumar, M.; Mukherji, S.; Chauhan, V.S.; Sarada, R.; Mudliar, S.N. Evaluation of indigenous fresh water microalga Scenedesmus obtusus for feed and fuel applications: Effect of carbon dioxide, light and nutrient sources on growth and biochemical characteristics. Bioresour. Technol. 2016, 207, 430-439. [CrossRef]

65. Gong, Y.; Guo, X.; Wan, X.; Liang, Z.; Jiang, M. Triacylglycerol accumulation and change in fatty acid content of four marine oleaginous microalgae under nutrient limitation and at different culture ages. J. Basic Microbiol. 2013, 53, 29-36. [CrossRef] [PubMed]

66. Shen, Q.H.; Gong, Y.P.; Fang, W.Z.; Bi, Z.C.; Cheng, L.H.; Xu, X.H.; Chen, H.L. Saline wastewater treatment by Chlorella vulgaris with simultaneous algal lipid accumulation triggered by nitrate deficiency. Bioresour. Technol. 2015, 193, 68-75. [CrossRef]

67. Rai, S.V.; Rajashekhar, M. Effect of pH, salinity and temperature on the growth of six species of marine phytoplankton. J. Algal Biomass Util. 2014, 5, 55-59.

68. Mirizadeh, S.; Nosrati, M.; Shojaosadati, S.A. Synergistic Effect of Nutrient and Salt Stress on Lipid Productivity of Chlorella vulgaris Through Two-Stage Cultivation. Bioenerg. Res. 2020, 13, 507-517. [CrossRef]

69. Juneja, A.; Ceballos, R.M.; Murthy, G.S. Effects of Environmental Factors and Nutrient Availability on the Biochemical Composition of Algae for Biofuels Production: A Review. Energies 2013, 6, 4607-4638. [CrossRef]

70. Delgadillo-Mirquez, L.; Lopes, F.; Taidi, B.; Pareau, D. Nitrogen and phosphate removal from wastewater with a mixed microalgae and bacteria culture. Biotechnol. Rep. 2016, 11, 18-26. [CrossRef] [PubMed]

71. Lugo, L.A.; Thorarinsdottir, R.I.; Bjornsson, S.; Palsson, O.P.; Skulason, H.; Johannsson, S.; Brynjolfsson, S. Remediation of Aquaculture Wastewater Using the Microalga Chlorella sorokiniana. Water 2020, 12, 3144. [CrossRef]

72. Scherholz, M.L.; Curtis, W.R. Achieving pH control in microalgal cultures through fed-batch addition of stoichiometricallybalanced growth media. BMC Biotechnol. 2013, 13, 39. [CrossRef] 
73. Ördög, V.; Stirk, W.A.; Bálint, P.; Staden, J.; Lovász, C. Changes in lipid, protein and pigment concentrations in nitrogen-stressed Chlorella minutissima cultures. J. Appl. Phycol. 2012, 24, 907-914. [CrossRef]

74. Li, Y.; Horsman, M.; Wang, B.; Wu, N.; Lan, C.Q. Effects of nitrogen sources on cell growth and lipid accumulation of green alga Neochloris oleoabundans. Appl. Microbiol. Biotechnol. 2008, 81, 629-636. [CrossRef] [PubMed]

75. Da Silva Ferreira, V.; Sant'Anna, C. Impact of culture conditions on the chlorophyll content of microalgae for biotechnological applications. World J. Microbiol. Biotechnol. 2017, 33, 20. [CrossRef] [PubMed]

76. Mohsenpour, S.F.; Richards, B.; Willoughby, N. Spectral conversion of light for enhanced microalgae growth rates and photosynthetic pigment production. Bioresour. Technol. 2012, 125, 75-81. [CrossRef] [PubMed]

77. Guillard, R.R.L.; Ryther, J.J. Studies of marine planktonic diatoms in Cyclotella nana Hustedt and Detonula confervacea Cleve. Can. J. Microbiol. 1962, 8, 229-239. [CrossRef] [PubMed]

78. Ratha, S.K.; Rao, P.H.; Govindaswamy, K.; Jaswin, R.S.; Lakshmidevi, R.; Bhaskar, S.; Chinnasamy, S. A rapid and reliable method for estimating microalgal biomass using a moisture analyser. J. Appl. Phycol. 2016, 28, 1725-1734. [CrossRef]

79. Ratomski, P.; Hawrot-Paw, M. Production of Chlorella vulgaris biomass in tubular photobioreactors during different culture conditions. Appl. Sci. 2021, 11,3106. [CrossRef]

80. Polish Standards PN-86 C-05560/02. Water and Waste Water. Tests for Chlorophyll in Surface Water, Determination of Chlorophyll a in Planktonic Algae by Spectrophotometric Monochromatic Method with Correction for Pheopigments Alpha; Polish Committee for Standardisation. 1986. Available online: https:/ /sklep.pkn.pl/pn-c-05560-02-1986p.html (accessed on 9 November 2020). (In Polish).

81. Shin, H.Y.; Ryub, J.H.; Baeb, S.Y.; Crofcheckc, C.; Crockera, M. Lipid extraction from Scenedesmus sp. microalgae for biodiesel production using hot compressed hexane. Fuel 2014, 130, 66-69. [CrossRef]

82. Polish Standards PN EN ISO 11905-1. Water Quality-Determination of Nitrogen-Part 1: Method Using Oxidative Digestion with Peroxodisulfate; Polish Committee for Standardization. 2001. Available online: https://sklep.pkn.pl/pn-en-iso-11905-1-2001p. html (accessed on 15 November 2020). (In Polish). 